clear; although symptoms were dramatically reduced, virus infection and seroconversion were not completely prevented. Possibly interferon only delayed the onset of the inevitable cold, but the limited evidence suggests that late colds were extremely mild. Although volunteers may have been susceptible to and caught their flatmates' colds when they finished treatment, virus isolation studies seem to show that virus persisted in the nose during treatment. Theoretically, with continued interferon treatment, virus replication would be reduced. It would then be necessary to continue treatment only until antibodies were formed to prevent clinical colds completely. An antiviral agent used widely in the prophylaxis of minor upper respiratory disease would clearly have an advantage if it allowed subclinical infection and an immune response. Furthermore, if interferon reduced absolute virus shedding and nasal secretions, transmission of colds could also be reduced.

We thank Mrs N Bailey, Miss J Robinson, and Mrs B Head for technical help; Dr P Higgins for helping with the administration of the trial; Mrs M Andrews for the care of the volunteers; Dr R S Lane and $\mathrm{Dr} \mathrm{K}$ Fantes for gifts of human albumin and interferon antibody respectively; and the volunteers for their enthusiastic co-operation.

Requests for reprints should be addressed to Dr G M Scott, Clinical Research Centre, Watford Road, Middlesex HA1 3UJ.

\section{References}

${ }^{1}$ Merigan TC, Reed SE, Hall TS, Tyrrell DAJ. Inhibition of respiratory virus infection by locally applied interferon. Lancet 1973;i:563-7.
${ }^{2}$ Harmon MW, Greenberg SB, Johnson PE, Couch RB. Human nasal epithelial cell culture system, evaluation of response to human interferons. Infect Immun 1977;16:480-5.

${ }^{3}$ Johnson PE, Greenberg SB, Harmon MW, Alford BR, Couch RB. Recovery of applied human leukocyte interferon from the nasal mucosa of chimpanzees and humans. 7 Clin Microbiol 1976;4:106-7.

${ }^{4}$ Greenberg SB, Harmon MW, Johnson PE, Couch RB. Antiviral activity of intranasally applied human leucocyte interferon. Antimicrob Agents Chemother 1978;14:596-600.

${ }^{5}$ Greenberg SB, Harmon MW. Effect of human interferon (HuIFN- $\alpha$ ) on prevention of rhinovirus infection and illness in man. In : De Maeyer E, Galasso $G$, Schellekens $H$, eds. The biology of the interferon system. Amsterdam: Elsevier/North Holland, $1981 ; 367-70$.

${ }^{6}$ Anonymous. Interferon production by genetic engineering. $\mathrm{Br} \mathrm{Med} \mathrm{F}$ $1981 ; 287: 674-5$.

${ }^{7}$ Cantell K, Hirvonen S. Large-scale production of human leukocyte interferon containing $10^{8}$ units per ml. F Gen Virol 1978;39:541-3.

${ }^{8}$ Secher DS, Burke DC. A monoclonal antibody for large-scale purification of human leukocyte interferon. Nature $1980 ; 285: 446-50$.

${ }^{9}$ Scott GM, Secher DS, Flowers D, Bate J, Cantell K, Tyrrell DAJ. Toxicity of interferon. $\mathrm{Br}$ Med $\mathcal{F} 1981$;282:1345-8.

${ }^{10}$ Secher DS. Immunoradiometric assay of human leukocyte interferon using monoclonal antibody. Nature $1981 ; 290: 501-3$.

11 Denham MJ, Foster A, Tyrrell DAJ. Work of a district ethical committee. Br Med f 1979;2:1042-5.

12 Tyrrell DAJ. Common colds and related diseases. London: Arnold, 1965 : 49-52.

${ }^{13}$ Scott GM, Reed S, Cartwright T, Tyrrell DAJ. Failure of human fibroblast interferon to protect against rhinovirus infection. Arch Virol 1980; $65: 135-9$.

${ }^{14}$ Aoki FY, Crawley JCW. Distribution and removal of human serum albumin-technetium $99 \mathrm{M}$ instilled intranasally by drops and spray. $\mathrm{Br} \mathcal{F}$ Clin Pharmacol 1976;3:869-78.

(Accepted 18 March 1982)

\title{
After-exercise thermography and prediction of deep vein thrombosis
}

\author{
A LINDHAGEN, D BERGQVIST, T HALLBÖÖK, B LINDROTH
}

\begin{abstract}
A total of 112 patients participated in a prospective study of after-exercise thermography as a screening method for predicting risk of postoperative deep venous thrombosis. The fibrinogen-uptake test was used to detect thrombosis after elective surgery. The incidence of the complication showed no significant difference between patients who had had positive and those who had had negative thermograms.
\end{abstract}

Thermography does not seem to be useful for predicting risk of postoperative thrombosis.

\section{Introduction}

After-exercise thermography shows a highly distinctive pattern in some patients. This pattern has been claimed to indicate deep venous insufficiency. ${ }^{1}$ In a prospective study of 109 patients $^{2}$ the pattern was associated with high risk of postoperative

Kärnsjukhuset S-541 85 Skövde, Sweden

A LINDHAGEN, MD, department of surgery

T HALLBÖOK, MD, department of surgery

B LINDROTH, MD, department of radiology

Allmänna Sjukhuset S-214 01 Malmö, Sweden

D BERGQVIST, MD, department of surgery thrombosis as detected by the fibrinogen-uptake test. As postoperative thrombosis is a multifactorial condition, devising a simple test to predict this risk presents great problems. We therefore conducted a prospective study to see whether afterexercise thermography in our hands could detect high-risk patients.

\section{Patients and methods}

We studied 112 patients (63 men, 49 women) aged 51-86 years (mean age 67.6 years). All were participating in a study of $\mathrm{pr} \mathrm{h}^{\text {-riaxis }}$ against postoperative thromboembolism. Dextran 70 was gi $i$ to 53 patients and a combination of dextran 70 and dihydroergota.nine to 59 patients. Elective hip replacement was performed in 65 cases and abdominal surgery in 47.

After-exercise thermography was performed preoperatively with the AGA 680 Medical System. A resting thermogram was recorded with the patient's legs $15-20^{\circ}$ above heart level after the unclothed legs had been exposed to room temperature for 10-15 minutes. The patient was then instructed to walk around the room or do knee-bends for two minutes. As soon as possible after the exercise a second thermogram was recorded with the patient positioned as before. A network of linear hot spots crossing the anterior tibia, not present on the initial thermogram, was regarded as positive. ${ }^{2}$

The ${ }^{125}$ I-fibrinogen-uptake test was used to detect postoperative thrombosis. The test was performed as described by Kakkar et al, ${ }^{3}$ but with slight modifications. ${ }^{4}$ Measured activity was correlated with the precordial activity. An increase in uptake of $20 \%$ or more as compared with adjacent points on two consecutive measurements was accepted as the criterion for deep venous thrombosis. The thermo- 
grams were interpreted by one of us (BL) before knowing the results of the fibrinogen-uptake test.

\section{Results}

After-exercise thermography gave positive results in 94 legs in 58 patients. Thus 36 patients had positive results in both legs. The fibrinogen-uptake test detected thrombosis in 27 legs in 26 patients; hence one patient had thrombosis in both legs. All thrombi were below knee level. Tables I and II summarise these results. The risk of developing thrombosis detectable by the fibrinogen-uptake test was $12.8 \%(12 / 94)$ in legs yielding positive thermograms and $11.5 \%$ $(15 / 130)$ in legs yielding negative thermograms. The difference was not statistically significant.

TABLE I-Results of after-exercise thermography and fibrinogen-uptake test. (Figures are numbers of legs)

\begin{tabular}{|c|c|c|c|}
\hline \multirow{2}{*}{$\begin{array}{c}\text { Result of } \\
\text { fibrinogen-uptake } \\
\text { test }\end{array}$} & \multicolumn{2}{|c|}{$\begin{array}{l}\text { Result of after-exercise } \\
\text { thermography }\end{array}$} & \multirow[t]{2}{*}{ Total } \\
\hline & Positive & Negative & \\
\hline $\begin{array}{l}\text { Positive } \\
\text { Negative }\end{array}$ & $\begin{array}{l}12 \\
82\end{array}$ & $\begin{array}{r}15 \\
115\end{array}$ & $\begin{array}{r}27 \\
197\end{array}$ \\
\hline Total & 94 & 130 & 224 \\
\hline
\end{tabular}

TABLE II-Results of after-exercise thermography and fibrinogen-uptake test (Figures are numbers of patients)

\begin{tabular}{ccccc}
\hline & \multicolumn{2}{c}{ Result of after-exercise thermography } & \\
\cline { 2 - 3 } $\begin{array}{c}\text { Result of } \\
\text { fibrinogen-uptake } \\
\text { test }\end{array}$ & \multicolumn{2}{c}{ Positive } & Negative & Total \\
\cline { 2 - 3 } & Unilateral & Bilateral & & \\
\hline $\begin{array}{c}\text { Positive } \\
\text { Negative }\end{array}$ & 4 & 10 & 12 & 26 \\
\hline Total & 18 & 26 & 42 & 86 \\
\hline
\end{tabular}

Positive after-exercise thermograriss from one or both legs were associated with a $24 \cdot 1 \%(14 / 58)$ risk of postoperative thrombosis, as compared with a $22.2 \%$ risk $(12 / 54)$ when both thermograms had been negative. The corresponding figures for bilaterally positive and unilaterally positive thermograms were $27 \cdot 8 \%$ and $18.2 \%$ (table III) None of the differences was statistically significant.

TABLE III-Incidences of postoperative deep vein thrombosis in patients with bilaterally negative, unilaterally positive, and bilaterally positive after-exercise thermography

\begin{tabular}{llcc}
\hline & \multicolumn{3}{c}{ Result of after-exercise thermography } \\
\cline { 2 - 4 } & $\begin{array}{c}\text { Bilaterally } \\
\text { negative }\end{array}$ & $\begin{array}{c}\text { Unilaterally } \\
\text { positive }\end{array}$ & $\begin{array}{c}\text { Bilaterally } \\
\text { positive }\end{array}$ \\
\hline No $(\%)$ of patients & $54(22 \cdot 2)$ & $22(18 \cdot 2)$ & $36(27 \cdot 8)$ \\
\hline
\end{tabular}

As expected, the incidence of thrombosis as detected by the fibrinogen-uptake test was higher in the patients who had undergone hip surgery than in the group given abdominal operations $(33.8 \%$ and $8.8 \%$ ). There was no significant difference in mean age $(67.8$ and $67 \cdot 2$ years) or sex ratio between patients who had had positive and negative thermograms. The type of thrombosis prophylaxis and type of operation did not significantly influence the incidence of thrombosis in relation to the result of after-exercise thermography (table IV).
TABLE IV-Incidence of thrombosis as detected by fibrinogen-uptake test in relation to result of after-exercise thermography, type of thrombosis prophylaxis and operation. Results expressed as number (\%) of patients

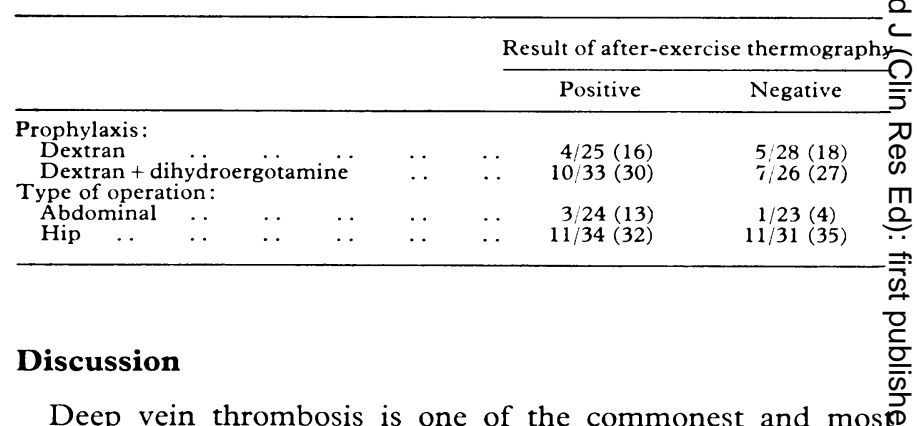

Deep vein thrombosis is one of the commonest and mos important complications of surgery. Hence much effort has been aimed at finding a test that will detect patients at high risk. Most of this work has been directed towards disclosing changes $\vec{\rho}$ in the coagulatory system. The techniques, however, are complex and expensive and therefore unsuited to routine practice. In 1978 Henderson et al ${ }^{2}$ reported that a characteristic pattern in thermograms made after exercise could help to predict. the risk of postoperative thrombosis. Using the fibrinogen uptake test they found thrombosis after abdominal surgery in 11\% of patients who had had bilaterally negative thermograms $63 \%$ of those who had had unilaterally positive thermograms and $92 \%$ of patients who had had bilaterally positive thermo $\vec{\infty}$ grams. After elective hip operations the corresponding figures్లు were $30 \%, 56 \%, 75 \%$. Statistically the results were highlyo significant.

We failed to reproduce these results, though our criterion for a positive thermogram was that used by Henderson et al. ${ }^{2}$ The pattern in a positive thermogram is characteristic, but there ared borderline cases in which interpretation is difficult, especially ito the patient has varicose veins. The true nature of the changes causing the characteristic pattern is still obscure. In another study (unpublished observations) our group was unable to correlate the pattern with deep venous insufficiency as measureos from ambulatory venous pressure or by plethysmography.

The patients in our series were somewhat different from those्ठ described by Henderson et al. ${ }^{2}$ Our patients were older. Als $\varrho$ they had received prophylaxis against postoperative thrombosis $\vec{F}$ Though this prophylaxis may have influenced the results, if seems improbable that the thromboses so prevented were thos that might be predicted by after-exercise thermography.

In conclusion, we were unable to show that a positive after exercise thermogram is of value for predicting postoperative thrombosis as detected by the fibrinogen-uptake test.

\section{References}

1 Cooke ED, Pilcher MF. Deep vein thrombosis: preclinical diagnosis by thermography. Br 7 Surg 1974;61:171.

2 Henderson HP, Cooke ED, Bowcock SA, Hackett MEJ. After-exercis $D$ thermography for predicting postoperative deep vein thrombosis. BRㅡㅡㄹ Med F 1978;i:1020.

${ }^{3}$ Kakkar VV, Howe CT, Flanc C, Clarke MB. Natural history of post operative deep vein thrombosis. Lancet $1969 ;$ ii $: 230$.

4 Bergqvist E, Bergqvist D, Bronge A, Dahlgren S, Hallböök T. Diagnosis of venous thrombosis in the lower limb. A comparative study betweer ${ }^{125}$ I-fibrinogen test, strain-gauge plethysmography and phlebographye Ups 7 Med Sci 1973;78:194.

(Accepted 16 April 1982)

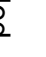

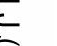

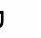

,

,

(1)

